\title{
Exploring Students Perceptions of Blogs During Teaching Practice Placements
}

\author{
Micheal M van Wyk \\ Department of Curriculum and Instructional Studies, \\ School of Teacher Education, College of Education, \\ University of South Africa, Pretoria, vwykmm@unisa.ac.za
}

Doi:10.5901/mjss.2013.v4n14p525

Abstract

From the onset, blogs served as personal social networking tools. More recently, blogs have facilitated the formation of online social networked communities and have thus expanded to more extensive uses in education. This paper explore the use of blogs to foster e-learning communities in empowering and supporting Post Graduate Certificate of Education (PGCE) students, who were learning to teach Economics education in open distance learning (ODL) environments. A "blog" for Economics education subject didactics students was created during their teaching practice period. Student teachers were encourage to post their views on the "Econblog" as a communicative platform to critically reflect on their learning processes as well sharing teaching practice experiences to enhance professional growth. Data collected was qualitative in nature, consisting of student teachers' posting reflections and comments on the "blog". Findings indicated that blog" as an e-learning tool promoted good relationships amongst student communities, support by exchanging ideas and information on teaching practice, provide opportunities to interact, entering into dialogue and reflective practice. Students alluded to challenges faced during teaching practice placements.

Keywords: blog, teaching practice, Economics education, Post Graduate Certificate of Education (PGCE), open distance learning $(\mathrm{ODL})$

\section{Introduction}

The $21^{\text {st }}$ century brought several challenges to the higher education arena regarding budgetary constraints, changing student profiles, demanding quality assurance practices, efficient course delivery modes, reliable assessment practices and the impact of globalization. These challenges places high demands on institutions of higher learning sector to deliver quality teaching and learning. With new forms of higher education emerging and the convergence of traditional forms to open learning units at higher education; there is increasing evidence of the way of course delivery, different role of academics, effective teaching methods and changing student support systems. The challenge for institutions of higher learning is to make provision for a technology integrated teaching and learning mode other than the conventional face-toface method to accommodate the digital natives and empowering the digital immigrants. Jegede (2009) posit that it is a system characterised by physical separation between the lecturer and student, in which instruction is delivered through a variety of media including printing and other information communication technologies (ICT). My contention is we cannot teach as we were trained during the 1980's compare to the current student profile which was born during the 1990's. These students are called the Net Generation or the digital natives. These digital natives bring new challenges to the teaching and learning environment. We must either adapt or be redundant in this millennium. The challenge for academics and management is how to respond to this global challenge. The question is: how are academics respond to this $21^{\text {st }}$ century challenge and how can they create enabling environments for effective online teaching and learning spaces? Numerous research studies have indicated the learning effect of teaching blogs for online learners. One particular web 2.0 social media tool, blogs, which could be used as an effective educational tool, is explored for the purpose of this study.

This paper explores Economics education student teachers' views of blogs as an educational tool and what they were responding to questions formulated during teaching practice. The blog postings and short social media survey responses were recorded, and data analysed was done. The focus of this study is, therefore, to explore and gain a deeper understanding of the educational value of blogs and how blogging supports students during the teaching practice and learning experience during school placements. Accordingly, an interesting question, which has driven this study, is whether blogs can support and strengthen teaching practice in student teachers of Economics education. This is similar to what has also been described as a community of practice (Wenger 1998). The aim is to collect evidence from student teachers' responses to the short social media survey and unstructured blog postings. Descriptive statistical analysis and 
various themes were analysed in exploring and comparing students' comments, before suggestions and conclusions were made on the implications for open and distance learinng (ODL) teaching practice education.

\section{Literature review}

In this section of this paper, the social networked theory, the usage of blogs in educational settings and the context of the study are explained.

\subsection{Social networked theory}

We tend to think of social media and networking as relatively new phenomena in teaching and learning in higher learning. But many popular social media tools are built on concepts within social network theory, a preeminent research field within social constructivism, sociology and organizational behaviour (Burt 1992; Uzzi 1996). Social networked theory examines specific dynamics within webs of interrelationships among people and firms. In this article, the researcher explores the concepts of social network theory that underlie the power and popularity of social media such as blogs as an e-learning facilitation strategy during teaching practice placements for post graduate certificate of education students in an ODL context. The researcher is of the opinion that lecturers often see new technologies as threatening their scholarly authority, precisely because these technologies require a re-thinking of roles, but this threat only materialises if we stay locked in a binary framework of lecturer versus student teacher. This applies especially to Web 2.0 technologies such as blogs used by the researcher in this study in a course as both student teachers and lecturers potentially bring different technological pedagogical content knowledge and skills to the ODL platform, and are thus joined in a collaborative community of practice learning journey.

\subsection{The usage of blogs in educational settings}

Several research studies have focused on the use of blogs in educational settings (Glogoff 2007; Huffaker 2005). On the other hand, some researchers still employ traditional computer-mediated communication (CMC) applications (e.g. email) to enhance students' communication and collaboration (Panda 2010; Bloch 2002). From the onset, blogs served as personal social networking tools. More recently, blogs have facilitated the formation of online social networked communities and have thus expanded to more extensive uses in education. Little has been learned about using blogs as a collaboration tool in educational contexts, especially in disrupted traditional communication and learning methods in the classroom in the last years (Anderson 2007; Ellison and Wu 2008). Today's college students spend lots of time on the internet and engage instant messaging, blogging, using Facebook or Twitter, downloading audio and video files, and online games in their daily lives. In other words, today's college students have grown up with these tools (Roberts et al. 2005). The dichotomy used for these kinds of students in the literature is "digital natives" or "virtual generation" (Ajjan and Hartshorne 2008; Pascu 2008; Anderson 2010). Blog is short for web log that is one of the most appealing Web 2.0 social media tools. It basically allows users to create personal journals and resource sites to share with their community (Makri and Kynigos 2007). Since its breakthrough among other online social media, the number of blogs has been increasing rapidly every day (Pascu 2008). With its increasing popularity, blogs have come out in a variety of fields including business, travel, sports, and also education. Educational applications of blogs include writing, researching, interpreting, interacting, reflecting, problem solving, cooperating, sharing ideas, and expressing individual or group voice (Brescia and Miller 2006).

These blog potentials could enrich learning experiences and lead to deeper learning. Rosie cited in Bartlett-Bragg (2003) elaborated that deep learning involves constructing connections between concepts in a context. Rosie added that deep learning is unlike surface learning where students complete the minimum content necessary to meet assessment requirements'. Furthermore, blogs offer a socially situated, student centred, contemporary, technical solution' (O'Donnell 2005), and catering for individual self-expression and socially driven learning (Farmer et al. 2008). Student-centred learning is enabled in blog monologues that enhance constructivist cognition and meta-cognition (higher order thinking).

\subsection{Context of the study}

The context for this study involves an ODL community (open distance learning-university), the school-based learning (ten week teaching practice at school level), and the social (economics education male and female students) and culture 
identities (race groups, mother tongue, language of instruction) of student teachers (see figure 1). This is consistent with Lave and Wenger (1991) view of knowledge is contextualised which is influenced by context, actions and culture in a particular community. In this study the variable of collaboration and dialogue requires an environment of shared objectives, peer learning dialogical spaces and personal experiences and relationship amongst fellow Economics education student teachers. One particular variable, cultural, is an important component of the ODL context and space. In view of these comments, this study investigates how a Web 2.0 social media tool, blogs, influenced student teachers personal experiences in real life situations. The teaching practice dialogical space is a system of knowledge, beliefs, behaviours and customs of a PGCE community of practice at an ODL institution of higher learning. Furthermore, as Pallof and Pratt (2003) as well as Mesirow (1991) argue that transformation is most important variable in this conceptual design and is the final form of "real" learning that takes place in an ODL setting (communities of practice).

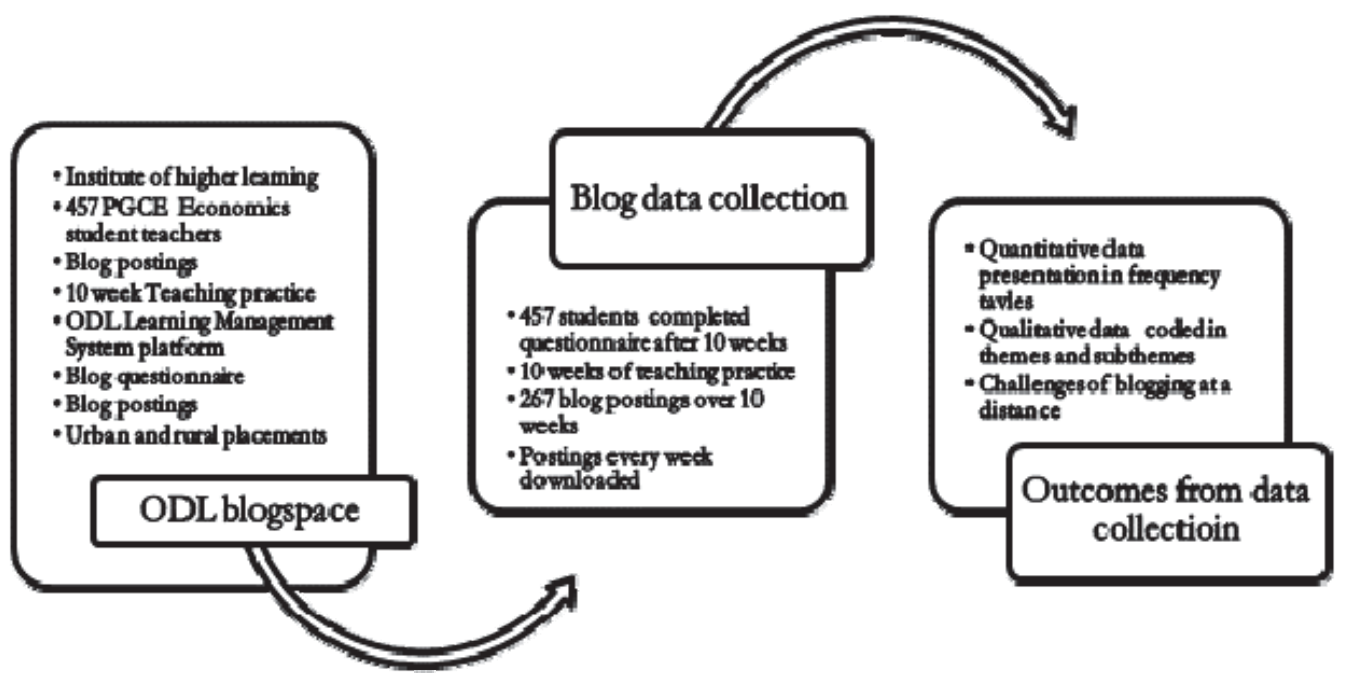

Figure 1 Blog design for teaching practice placements

\section{Research Methodology}

Research design: A positivist-interpretive paradigm is employed for this exploratory study. A qualitative research method was employed. A Google scholar desktop search was conducted on peer reviewed articles on "blogs as an educational social media tool".

Participants: Four hundred and fifty seven ( $\mathrm{n}=457)$ completed the online questionnaire and two hundred and sixty seven $(n=267)$ blog posting were captured, who were learning to teach Economics education in open distance learning (ODL) environments participated on the blogspace.

Data collection instruments: for the qualitative data collection, PGCE student teachers' blog postings were used for the purpose of conducting this study. Three data collection instruments were designed to elicit responses regarding the exposure of a social media tool such as "blog" e-learning communities' postings during the teaching practice online learning management system. Students' reflective blog postings entries from "Econblog" were collected recorded and thematically analysed.

Ethical clearance: Before the researcher could begin with the study, consent was obtained from the students. The researcher explained the purpose of the study. Further, then the purpose of confidentiality to the participants was explained. The researcher decided beforehand to use no names of students for this study.

\section{Findings}

Data was analysed and presented in the form of mean scores, standard deviations, reliability test, correlations between surveys employed as well blog postings for the purpose of conducting this investigation regarding student teachers' blogspace. 


\section{Quantitative data analysis of blogs}

Table 1. Perceived Learning of blogs during teaching practice $(n=457)$

\begin{tabular}{|l|l|l|}
\hline & Mean & SD \\
\hline The blog discussions help me to share my knowledge and experience with my peers & 3.88 & 1.89 \\
\hline I believe that incorporating blogs with teaching can enhance my learning experience in general. & 3.03 & 0.73 \\
\hline Other students' comments on my blog posts are important & 3.41 & 0.89 \\
\hline Blog discussions help me understand other points of view. & 2.58 & 1.22 \\
\hline Blog discussions have made me think about teaching practice during my placement. & 3.84 & 2.00 \\
\hline My point of view has been acknowledged by my peers and/or discussion lecturer in this module & 3.46 & 2.39 \\
\hline Overall using the blog has helped me learn. & 3.65 & 1.67 \\
\hline
\end{tabular}

1=Strongly disagree, 2=Disagree, 3=Agree, and 4=Strongly agree.

In reference to Table 1, respondents agreed that perceived learning of blogs during teaching practice empower them to teach economics education. Results revealed the blogs have great effect on teaching and learning in during teaching practice placements. According to the results blogging has its greatest instructional potential for those who maintain a blog throughout their blog discussions which help them to share their knowledge and experience with their peers $(M=3.88, S D=1.89)$. Blog discussions have made them think about teaching practice during school placements ( $M=3.84$, $S D=2.00)$ and overall blogs has helped them to learn to teach Economics education $(M=3.65, S D=1.67)$.

Table 2. Blogs as a Community of Practice $(n=457)$

\begin{tabular}{|l|l|l|}
\hline Blogs as a Community of Practice & Mean & SD \\
\hline I visit our group blog more than required by my instructor. & 3.31 & 2.39 \\
\hline The blog helps me feel connected to other students in this course & 3.69 & 2.23 \\
\hline Due to class blog, I feel that I am an important part of our classroom community & 3.90 & 2.59 \\
\hline I have been stimulated to do additional readings or research on topics discussed on the blog. & 3.42 & 3.39 \\
\hline $\begin{array}{l}\text { In comparison to my other classes, the amount of interaction with other students in this class } \\
\text { has increased due to the blog. }\end{array}$ & 3.67 & 1.77 \\
\hline $\begin{array}{l}\text { In comparison to my other classes, the quality of interaction with other students in this class } \\
\text { has increased due to the blog }\end{array}$ & 3.24 & 1.89 \\
\hline
\end{tabular}

1=Strongly disagree, 2=Disagree, 3=Agree, and 4=Strongly agree.

In reference to Table 2, respondents agreed that blogs as a community of practice support perceived learning during teaching practice. Results revealed the blogs have great effect on teaching and learning in during teaching practice placements. According to the results blogging has its greatest instructional potential for those who maintain a blog throughout their blog discussions due to class blog, I feel that I am an important part of our classroom community which $(M=3.90, S D=2.59)$. The blog helps me feel connected to other students in this course $(M=3.69, S D=2.23)$ and In comparison to my other classes, the amount of interaction with other students in this class has increased due to the blog $(\mathrm{M}=3.67, \mathrm{SD}=1.77)$.

Table 3. Collaborative learning through blogs $(n=457)$

\begin{tabular}{|l|l|l|}
\hline Collaborative learning through blogs & Mean & SD \\
\hline $\begin{array}{l}\text { Collaborative learning experience in the blog supported environment is better than in a face- } \\
\text { to-face learning environment }\end{array}$ & 3.41 & 1.39 \\
\hline I felt part of a learning community in my group & 3.21 & 1.23 \\
\hline I actively exchanged my ideas with group members & 3.58 & 1.89 \\
\hline I was able to develop new skills and knowledge from other members in my group & 2.67 & 1.72 \\
\hline I was able to develop problem solving skills through peer collaboration. & 3.01 & 2.10 \\
\hline Collaborative learning in my group was effective & 2.66 & 1.39 \\
\hline Collaborative learning in my group was time consuming & 3.00 & 1.77 \\
\hline Overall, I am satisfied with my collaborative learning experience in this course & 3.47 & 2.11 \\
\hline
\end{tabular}

1=Strongly disagree, 2=Disagree, 3=Agree, and 4=Strongly agree. 
Table 3 reported that respondents agreed that blogs support collaborative learning during teaching practice at school level. Results revealed the blogs have great effect on teaching and learning in during teaching practice placements. According to the results blogging has its greatest instructional potential for those who maintain a blog throughout their blog discussions due to class blog, they actively exchanged ideas with group members $(M=3.58, S D=1.89)$. Respondents were satisfied with their collaborative learning experience in this course $(M=3.47, S D=2.11)$ and Collaborative learning experience in the blog supported environment is better than in a face-to-face learning environment $(M=3.41, S D=1.39)$.

Table 4. Internal reliability, correlations, means and standard deviation ( $\mathrm{N}=457)$

\begin{tabular}{|l|l|l|l|l|l|l|}
\hline \multicolumn{2}{|l|}{ Three surveys on student learning } & $\begin{array}{l}\text { Original } \\
\mathrm{a}=0.7\end{array}$ & $\begin{array}{l}\text { New } \\
\mathrm{a}=0.7\end{array}$ & 1 & 2 & 3 \\
\hline 1 & Perceived Learning & 0.80 & 0.89 & 1 & & \\
\hline 2 & Community of Practice & 0.79 & 0.92 & $0.56^{\star}$ & 1 & 1 \\
\hline 3 & Collaborative Learning & 0.82 & 0.90 & 0.24 & $0.48^{\star}$ & $0.68^{\star}$ \\
\hline Mean & & & 3.88 & 3.39 & 3.15 \\
\hline SD & & & 0.73 & 0.90 & 0.68 \\
\hline
\end{tabular}

${ }^{*} p<0.01$

Overall seen in Table 4, the reliability test, Cronbach's alpha internal consistency coefficient was higher compared to the original scales on all the three of the surveys used in this study. All three data collection instruments were validated for purpose of this study. Emanating from this, students considered "Econ blog" as beneficial for Perceived Learning use $(M=3.88, S D=0.73)$ compared to Community of Practice $(M=3.39, S D=.90)$. Evaluation of students' perceptions of the Collaborative Learning of blogs during teaching practice indicated that the blog space promote learning through a community of practice $(M=3.15, S D=0.68$. Overall all three instruments show significant changes in perceived learning by blogs as a supportive and empowering tool during teaching practice placements at school levels. Pearson correlation coefficients were computed. Student teachers' benefits of "blogspace" had statistically significant correlations with Perceived Learning $(r(457)=.56, p<.01)$, Community of Practice $(r(457)=.48, p<.01)$ and Collaborative Learning $(r$ $(457)=.68, p<.01)$. In summation, positive experiences and statistically significant correlation with student teachers' teaching practice learning during the ten week placements were revealed.

\section{Qualitative data analysis}

The following themes emerged from the PGCE student blog postings:

\section{Building relationships amongst student communities}

Most of the students' postings indicated that blogs encouraged collaboration amongst peers and integration of personal views on how to build good relationship amongst them. They also referred how they support each other and advice given during teaching practice. They learned a lot from each other and also gained access to information about other placements. One student comment:

I was in social space but it felt to me that I was more on par what was happening during teaching practice placements. We contacted other classmates on classroom management. We (three students at one secondary school) supported each other at our placement school. Our mentor helped us on administration issues. We then shared with other students at other sites. Through this action, we build good relationships among students because of the blog postings.

Specifically, students believed that a social learning process that takes place when individuals, with a common interest or outcome, share their ideas and experiences over time to find new ways. Furthermore students' postings reflected that blogs is a useful tool to promote discussion within a select e-learning community of practice.

\section{Exchanging ideas and information on teaching practice}

Student postings reflected that it was an excellent tool exchanging insights and ideas about teaching practice. The 
following posting depicted sharing of information: It was a huge learning experience on how we shared teaching practice information regarding on how to teach big classes. I appreciate how my fellow students shared ideas on strategies on how to teach indiscipline learners. We felt so empowered. Students felt that it was useful to share their own experiences with others and to compare these with the experiences of same subject didactics students.

\section{Opportunities to socialise interact and enter into dialogical spaces}

Students indicated that the "blogspace" was an effective social connection to other classmates, especially if you are alone placed at a school. They believed it was particularly valuable and reduced the sense of isolation during their teaching practice period. One student responded: I was connected with other PGCE students who I did not knew before. We started even after the blogspace, we connect on Facebook. It is an excellence way for haring good ideas during our practicals. Yes, I like the way we chat using blogs in the classroom. I think idea is brilliant and I will experiment in my economics class. Students also felt that they could enter the dialogical space that they would not normally discuss at school level. They also appreciated the relatively quick feedback from the lecturer's postings. The whole idea of getting peer feedback was a novel concept for some students and they found this very beneficial.

\section{Reflection about teaching practice placements}

The blog required students to reflect on their teaching sessions in the subject practice which they found beneficial as it "forced you to reflect... you had to make time to stop and think about the lesson presentations. What work well, where you must still work on other classroom management issues". I always think what work and did not work in my lesson presentation. The input from peers, as well as the lecturer, also expanded the network of other subject student teachers. It also seemed from the "bloggings" that it take time to get the blogging groups to a level where contributions were more robust. This is what some of them said:

We did rethink our teaching placements. We blogged our experiences and challenges during our first two weeks during school visits. We reflected seriously about our placements and provide some suggestions on how to better future placements. Some students placed brilliant ideas on how we could strengthen our placements.

Students felt that it gave them an opportunity to process their thoughts and structure them in a more useful manner in writing them down, knowing that they were going to be read by four or five others. The blog was a non-threatening and safe space where the students could ask, 'stupid' questions.

\section{Challenges faced during teaching practice}

Some students said that accessibility to the Internet at teaching practice ecologies was for some of them a challenged to respond to certain topics for discussion on the blog. One student remarked: I was placed in a rural school and no connectivity was available to blog or sometimes the reception was not good. I could only respond five hours after arriving at my home. This reduced opportunities for social co-construction to develop professionally. One female student replied: We were not aware and some of my other classmates registered late for this course and missed the first round of reflections. Some students reported that they heard from other subject didactics students that there was an Economics education blog for teaching practice. Some students only entered their blogs towards the end of their placement, which meant there was a flurry of activity at the end. This again diminished the learning value because there was not enough time to build up a stream of ideas, get feedback and implement suggestions. They posted their blogs towards the end of their placement. One male student was really upset and felt it was unfair not to be informed: I did not received the e-mails nor any SMSs announcement which informed me that there will be an Economics blog... I did not have any access to the Internet... my Black Berry phone was in for repairs... Internet data is very expensive...sometimes there is no money to buy "internet data". Most students also did not have access to the Internet at their placements because of site restrictions. This meant they had to do the blog on their own time whereas it could have been beneficial to do this at the placement site if time was available. Some students provided suggestions that the guidelines to follow a particular topic for teaching practice placements which must be set in place before starting a blog. One female student said: I would like that we start every weekend with a specific topic such as teaching methods or class disciple. Here are some questions we could use during or teaching practicals. How to teach a class size of 50 learners? How will you organise such a class? What teaching method(s) can I employ in such a class? 


\section{Discussion}

Findings revealed that student teachers during teaching practices at different placements collaborated by peer learning, starting dialogical spaces, sharing personal experiences and relationship amongst them. Yang (2009), as well as Killeavy and Moloney (2010) investigated the use of blogs as a reflective platform in the training processes and found that participants actively discussed their opinions about the topics through blogs. Students stated that blogs provide a useful platform for reflecting and communicating with each other. Student teacher reflections posted on blogs have positive influence on the growth of professional knowledge and capacity. Overall all three instruments show significant changes in perceived learning by blogs as a supportive and empowering tool during teaching practice placements at school levels. Pearson correlation coefficients were computed and student teachers' benefits of "blogspace" had statistically significant correlations with Perceived Learning $(.56, p<.01)$, Community of Practice $(.48, p<.01)$ and Collaborative Learning (.68, $p<.01)$.Students indicated positive experiences during the school placements. Students wrote that they reflect on their teaching sessions in the subject practice which they found beneficial. Some responded that we were "forced to reflect... you had to make time to stop and think about your teaching practice". In another study, Makri and Kynigos (2007) analyzed the integration of group blogging in a postgraduate course. Blogging was integrated as a medium of asynchronous communication and reflection. The positive benefits gained from this blog experience demonstrate that ICT, in combination with peer coaching, can build the capacity of the novice professional in an ODL teaching practice context. Any discipline that has work integrated learning (school-based learning) such a teaching practice, could benefit from the use of blogs. Students said that the blog was particularly valuable and reduced the sense of isolation during their teaching practice period. For example, pre-service teachers that undergo teaching practices in schools could be networked via blogs to discuss their experiences as teachers and in implementing curriculum. One particular blog posting reflected that some students placed brilliant ideas on how they could strengthen their placements, which supported the idea to empower students throughout the teaching practice learning experience. The blog experience was able to support students through the range of teaching practice sessions, as well as creating opportunities to explore evidence based practices in the school setting. Many of the same issues were noted by comments of the students, for example, the neutrality and informality of blogging and the value of learning about how others see the same question (Williams and Jacobs 2004; Farmer et al. 2008). The social constructivist discourse that took place also enhanced students' and academic moderators' understanding of professional practice dilemmas and issues. This is certainly consistent with the evidence supporting learning through computer mediated discussion, particularly when linked to practice and feedback (Churchill 2009). The operational aspects of the blog facilitated this discourse and were an effective medium for creating a community of practice among the students and academic moderators (Glogoff 2007; Churchill 2009; Yang 2009; Killeavy and Moloney 2010). The need for reflection, as part of the experiential learning cycle, and the development of professional competence was also reinforced by the use of blogs, especially in advancing student teachers in this study. The five metaspaces noted by Green (2005) were evident with students taking charge of learning issues, exploring critical elements of practice and sharing examples of professional skills. Spaces of trust were also quite resounding, and the value of having a neutral group of individuals, aside from those in authority, was highly valued by the students. The current study indicated that some student teachers did not take full advantage of the collaboration and peer feedback sessions. This impeded poor reflection or did not engage as fully as other students should and not be taken necessarily as a measure of learning effectiveness, even though some students were frustrated by some blogger's lack of input into the discussions. Moreover, Ellison and Wu (2006) as well as Nonnecke and Preece (2001) notes that 'lurkers', individuals who read but do not necessarily participate in the online discussion, may still be learning through their passive or vicarious participation. In terms of implementation practicalities, it was clear that student teachers need clear guidelines to support them in the blogging environment to optimise learning outcomes. For students, example blogs, and deadlines for original and return comments, are necessary as these drive blogging behaviour. Introduction earlier into the curriculum is important to develop competency in using blogs and in reflective writing and practice (Ellison and Wu 2008). Similar issues have been raised in other studies where blogs have been used to promote learning and discourse in higher education (Top et al. 2010; Farmer et al. 2008). Facilities should also consider providing students with Internet access while at their facilities to increase the timeliness of reflective writing and group feedback.

\section{Conclusion}

Findings indicated that positive implications of the "blog" as an e-learning community which promoted interactive communications, resource and opinion sharing, opportunities for collaboration and reflection, promoting opportunities to 
socialise, interact, entering into dialogue and assisting in building e-learning communities. Emanating from the use of blogs in a group of PGCE student teachers involved in an ODL teaching practice programme which assisted and empowering them with reflective practice, reasoning and added value to their learning experiences. The use of a social media space, such as a "blog" has perhaps highlighted the educational value especially in an ODL teaching practice context. Through this, student teachers discovered the value of ongoing reflective practice as a critical component of personal growth and professional development, and embrace the value of this social media tool in supporting their lifelong learning. In fact, any discipline, where reflective practice is an integral part of professional development may look towards blogs as an e-learning tool. However, the free access nature of blogging in this study provided student teachers with extended opportunities to build reflective practice networks of amongst student teachers who were engaged in a diverse and geographically spread ODL teaching placements programme at an institution of higher learning. Blog as a social media tool is undervalued and underutilised for the purpose of enhancing teaching and learning in an ODL teaching practice. There is much to be learned about the impact of blog use on student learning and course satisfaction.

\section{Practical Implications}

Finding and discussions from this research is motivated to recommend specific issues in relation to blogs as an educational tool. It is recommended that a more structured e-learning set up create to support student teachers how to read, write, respond, and reflect blog postings. The digital immigrant in this case the older generation student teachers must be empower to understand the familiarities on how to use and what procedures to follow when to post blog messages. To eliminate negative perception more is needed for student teachers (digital natives and digital immigrants) to spend more time learning how to use a blogging system effectively. Some participants received error messages and felt frustrated because they were not focusing on what the problems were, this change can be address by learning management system backup system. The merits of opening a blog to the Economics education students are to attract subject related views who are interested in the teaching practice experiences and to encourage higher levels of contributions. The lecturer should inform subject didactics students as to whether the blog is used for purpose professional growth and is restricted to registered students only. The subject didactics lecturer should advise them not to reveal the names of other students, teachers, or schools or institutions during the ODL teaching practice sessions. The subject didactics lecturer should offer a training session or placing procedures to demonstrate the blogging procedures, explaining the rationale and the advantages of blogging.

The results of this study should be interpreted with caution due to the following limitations. First, a bias may exist because of the self-selected sample of Economics education students. Second, the researcher who wants to better explore the phenomenon should develop more elaborate scales of research constructs for an ODL context. With the maturity of the associated technology, more and more innovative features have been integrated into blog functions, such as an embedded map that shows the locations of bloggers in real time, interaction via online chat on the blog, or incorporating the contents of other websites within the blog. Future researchers are encouraged to develop blog function scales that reflect the distinct characteristics of these new technologies. Third, based on their usage pattern, this study categorised bloggers into two subgroups, i.e. blog readers/writers and blog lurkers. The results suggested that these two groups differ in the perception of factors that affect their usage intention. Finally, this study employed a blog to collect empirical data. Further research could use an experimental design, which can further clarify the effects of social influence on the bloggers' usage intention. Finally, further research is needed to explore the different blog behaviours of students in an ODL context.

\section{Acknowledgements}

The author acknowledged the financial contributions made by the National Research Foundation of South Africa (NRF) for Grant funding. Acknowledgement is given to the Economics education students who voluntarily participated in this research study. Lastly, the quality of language revision work done by university language editing unit is highly appreciated. Any opinions, findings, and conclusions expressed in this paper are those of the author and do not reflect the views of the NRF or the Department of Curriculum and Instructional studies in the College of Education.

\section{References}

Ajjan H, Hartshorne R 2008. Investigating faculty decisions to adopt Web 2.0 technologies: Theory and empirical tests. Internet and 
Higher Education, 11(2):71-80.

Anderson P 2007. What is Web 2.0? Ideas, technologies and implications for education, JISC Technology and Standards Watch. Available from http://www.jisc.ac.uk/media/documents/techwatch/tsw0701b.pdf (Accessed 12 January 2012)

Anderson T 2010. Theories for learning with emerging technologies. In G. Veletsianos

(Ed.), Emerging technologies in distance education. Edmonton: Athabasca University Press. Available from http://www.aupress.ca/books/120177/ebook/02 Veletsianos 2010-Emerging Technologies in Distance Education.pdf. (Retrieved 16 January 2012)

Bartlett-Bragg A 2003. Blogging to Learn. The Knowledge Tree. 4th Edition. Available from http://knowledgetree.flexiblelearning.net.au/edition04/pdf/Blogging_to_Learn.pdf

(Accessed March 1, 2012).

boyd dm, Ellison NB 2008 .Social Network Sites: Definition, History, and Scholarship. Journal of Computer-Mediated Communication 13 (2):210-230

Brescia WF, Miller MT 2006. What's it worth? The perceived benefits of instructional blogging. Electronic Journal for the Integration of Technology in Education, 5:44-52.

Burt RS 1992. Structural holes. Cambridge: Cambridge University Press.

Churchill D 2009. Educational applications of Web 2.0: Using blogs to support teaching Educational Technology, 40(1):179-183.

Ellison NB, Wu Y 2008. Blogging in the classroom: A preliminary exploration of student attitudes and impact on comprehension. Journal of Educational Multimedia and Hypermedia, 17(1):99-122.

Ellison $\mathrm{Nb}$, Wu Y 2006. An empirical test of blogging in the classroom.

HigherEdBlogCon. Available from http://www.higheredblogcon.com/index.php/an-empirical-test-of-blogging-in-the-classroom/ (Accessed 13 March 2012)

Glogoff S 2007. Do Blogs Help Students to Learn? Learning and Teaching in Higher Education, 2(8):1-77. Available from http://resources.glos.ac.uk/shareddata/dms/EA360D46BCD42A0393D5D5E2FDCB3415.pdf (Accessed 12 March 2012).

Green P 2005. Spaces of influence: A framework for analysis of an individual's Contribution within communities of practice. Higher Education Research \& Development, 24(4):293-307.

Jegede $\mathrm{O}$ 2009. From convocation to flexible learning: The role of ODL in community development. ODL Occasional Lecture Series \#2. Institute for Open and Distance Learning. University of South Africa.

Killeavy M, Moloney A 2010. Reflection in a social space: Can blogging support reflective practice for beginner teachers. Teaching and Teacher Education, 26:1070-1076.

Lave J, Wenger E 1991. Situated learning: Legitimate peripheral participation. New York: Cambridge University Press.

Makri K, Kynigos C 2007. The role of blogs in studying the discourse and social practices of mathematics teachers. Educational Technology \& Society, 10(1):73-84.

Mezirow J 1991. Transformative dimensions of adult learning. San Francisco:Jossey-Bass.

Nonnecke B, Preece J 2001. Why lurkers lurk. Americas Conference on Information Systems. http://www.socs.uoguelph.ca/ nonnecke/research/whylurk.pdf. Retrieved March 12, 2012.

O’Donnell M 2005. Blogging as pedagogic practice: Artefact and ecology. Paper

presented at Blogtalk Downunder, Available from http://scholar.google.com/scholar?hl=en\&lr=\&client=safari\&cluster=5351964783984769932. (Accessed March 3, 2012)

Pallof R, Pratt K 2003. The virtual student: A profile and guide to work with online learners. San Franscisco: Jossey-Bass.

Pallof R, Pratt K 1999. Building learning communities in cyberspace. Effective strategies for the online classroom. San Franscisco: Jossey-Bass.

Panda S 2010. Social software, Social Networks, and Online Distance Leaning. $4^{\text {th }}$ Lecture in the ODL Occasional Lecture Series. Institute for Open \& Distance Learning. University of South Africa.

Pascu C 2008. An empirical analysis of the creation, use and adoption of social computing applications: IPTS exploratory research on social computing. Available from http://ftp.jrc.es/EURdoc/JRC46431.pdf. (Accessed February 01, 2012).

Roberts DF, Foehr UG \& Rideout V 2005. Generation M: Media in the lives of 8-18 year-olds. Washington, DC: Henry J. Kaiser Family Foundation. Available from http://www.kff.org/entmedia/7251.cfm. (Accessed February 01, 2012).

Top E, Yukselturk E, Inan FA 2010. Reconsidering usage of blogging in preservice teacher education courses. Internet and Higher Education, 13(4):214-217.

Uzzi, B. 1996. The sources and consequences of embeddedness for the economic performance of organizations: The network effect. American Sociological Review, 61, 674-698.

Wenger, E. 1998. Communities of practice: Learning, meaning and identity. Cambridge: CUP.

Williams, J., Jacobs, J. 2004. Exploring the use of blogs as learning spaces in higher education sector. Australasian Journal of Educational Technology, 20(2), 232-247. Retrieved on January 12, 2013 from http://www.ascilite.org.au/ajet/ajet20/williams.html

Yang, S.H. 2009. Using blogs to enhance critical reflection and community of practice. Educational Technology \& Society, 12(2):11-21. 
